DOT/FAA/AM-97/8

Office of Aviation Medicine Washington, D.C. 20591

\section{Where the Safety Rubber Meets the Shop Floor: A Confirmatory Model of Management Influence on Workplace Safety}

Richard C. Thompson

Thomas F. Hilton

Civil Aeromedical Institute

Federal Aviation Administration

Oklahoma City, Oklahoma 73125

L. Alan Witt

Barnett Banks, Inc.

Jacksonville, Florida

March 1997

Final Report

This document is available to the public through the National Technical Information Service, Springfield, Virginia 22161.

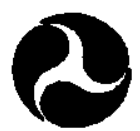

U.S. Department

of Transportation

Federal Aviation

Administration 


\section{NOTICE}

This document is disseminated under the sponsorship of the U.S. Department of Transportation in the interest of information exchange. The United States Government assumes no liability for the contents or use thereof.

PROTECTED UNDER INTERNATIONAL COPYRIGHT ALL RIGHTS RESERVED.

NATIONAL TECHNICAL NNFORMATION SERVICE

U.S. DEPARTMENT OF COMMERCE 
Where the Safery Rubber Meets the Shop Floor: A Confirmatory

Model of Management Influence on Workplace Safety

7. Aushor(d)

Thompson, R.C., Ph.D.; Hilton, T.F., Ph. D.; and

Witt, L.A., Ph.D.'

9. Performing Organization Name and Addraes:

FAA Civil Aeromedical Institute

P.O. Box 25082

Oklahome City, OK 73125

12. Sponsoring Agency name and Address

Office of Aviation Medicine

Federal Aviation Administration

800 Independence Ave., S.W.

Washington, DC 20591

'Barnett Banks, Inc.

Jacksonville, FL
3. Recipient's Catalog No.

5. Roport Dats

March 1997

6. Performing Organization Coda

8. Parforming Organization Roport No.

10. Work Unit No. (TRAIS)

11. Contract or Grant No.

13. Type of Report and Period Covered

14. Sponsoring Agency Code

15. Supplemental Notes

\section{Abstrect}

The role of management in establishing a safe work environment remains a topic that receives less attention in the literature than it deserves. Many authors have focused on safety programs and associated indications of program effects. Prescriptive articles advocating various management behaviors abound. However, there is little empirical evidence that validates the important role management plays in establishing 2 climate that sustains safe job behaviors. There is even less information about how management influences the safety atmosphere of the workplace. This paper presents a model that links management support, organizational climate, and self-reported safery outcomes. Confirmatory factor analysis results indicate that managerial influence on safery behaviors varies as a function of management role (manager/supervisor) and safety outcomes (safety conditions/safety compliance). We developed the model on data collected in 1992 and confirmed it on data collected in the same organization (the Federal Aviation Administration's Logistics Center) in 1995. Results underscore the important role management plays in maximizing workplace safety.

17. Kor Worde

Organizational Climate, Safety Climate, Safety Perceptions
18. Distribution Statement

Document is available to the public through the National Technical Information Service Springfield, Virginia 22161

\begin{tabular}{|c|r|}
\hline $\begin{array}{c}\text { 19. Security Classif. lof this report) } \\
\text { Unclassified }\end{array}$ & $\begin{array}{r}\text { 20. Security Classif. lof this pagel } \\
\text { Unclassified }\end{array}$ \\
\hline
\end{tabular}

Form DOT F 1700.7 (8-72)

\begin{tabular}{|c|l|}
\hline 21. No. of Pages & 22. Price \\
12 & \\
\hline
\end{tabular}

Reproduction of completed page authorized 


\section{Where the SAfety Rubber Meets the Shop Floor: A Confirkitary Model of Management Influence on Workplace Safety}

\section{INTRODUCTION}

There has been little empirical research into understanding how managers can promote workplace safety (e.g., Myers \& Facteau, 1992). However, it is well established that management's actions affect employee perceptions of their organization and its safety priorities (Cohen, 1977; Myers \& Facteau, 1992; Tuttle, Dachler, \& Schneider, 1975; Zohar, 1980). Management can communicate what is important in explicit and tangible ways through stated goals, rewarding job behaviors, establishing policies and procedures, etc. Each of these actions, in turn, contributes to an organization's climate (Schneider $\&$ Rentsch, 1988). The climate of every organization includes a safery component.

When safety researchers examine organizational climate, their primary focus is usually to relate general components of an organization's climate (e.g., communication, management concern, management trust) to safety outcomes (Brown \& Holmes, 1986; Coyle, Sleeman, \& Adams, 1995; Dedobbeleer \& Belland, 1991; Zohar, 1980). Because safety is rarely the focus of climate research, there has been little attention paid to how managers can influence their organization's climate to improve workplace safety. Without some dynamic model to indicate how climate relates to safety, it is difficult for managers to understand their role in creating and maintaining a safe workplace. This might help to explain why many managers express concern that despite stated support for their safety programs, workplace safety does not seem to improve.

Cohen, Smith, and Cohen (1975), Cleveland, Cohen, Smith, and Cohen (1978), and Janssens, Brett, and Smith (1995) have all demonstrated that management involvement and support are significant factors in establishing and maintaining a safe workplace. A number of authors have even linked workplace safety to management behaviors and various organizational climate factors (e.g., Dejoy, 1985, 1994; Myers \& Facteau, 1992; Zohar, 1980). Yet, despite the widespread acceptance that organizational climate and management support for safety are related to workplace safety, very little research has been conducted to explore the nature of the relationship between these variables. This paper attempts to model the relationship between climate, management support for safety, and workplace safety.

Focus discussions with shop floor employees indicated a vague perception that management policy and practice often sent inconsistent messages. This inconsistency in actions and woris led employees to question priorities and whether safe behaviors were likely to be rewarded. Witt, Helman, and Hilton (1994) formulated the hypothesis that three climate factors might be strongly influencing safety: (a) confusion over organizational goals (goal incongruence), (b) the perception that it would be impolitic to elevate safety issues to management (politics), and (c) the perception that elevated safety concerns might not be given a fair hearing (fairness).

\section{Goal Congruence}

Vancouver and Schmidt (1991) demonstrated that lack of workforce-management congruence about organizational goals can adversely impact workforce perceptions. Goal incongruence can also affect other climate-related outcomes (Schneider, 1987). Policypractice inconsistency can have other effects. For instance, Dejoy $(1985,1994)$ pointed out that employee attributions about management intentions can be a key influence on safety perceptions. For example, if management is perceived as willing to set aside safe practices to meet production goals, employees are likely to attribute management's support for safety as being perfunctory. This could lead some employees to conclude that cutting corners will be rewarded. 


\section{Organizational Politics}

Organizational politics involves influencing the decision making of others in an organization through means outside the formal organizational structure (Drory \& Romm, 1990). Politics can include such actions as social ingratiating, hiding agendas, or not elevating unpleasant or controversial matters. Political behavior is generally perceived to be a negative attribute that communicates the political actor's needs are being placed above the needs of the organization and other individuals (Drory \& Romm, 1990; Gandz \& Murray, 1980). Also, managers report that organizational politics occurs more frequently at middle and upper management levels (Madison, Allen, Porter, \& Renwick, 1980). Generally, Kacmar and Ferris (1991) have shown that there are various dimensions associated with the politics construct. The dimension considered most relevant to safety was the "go along to get ahead" dimension, which emphasized not sending disagreeable messages to management. The general level of political behavior in an organization has been shown to influence the degree to which employees believe and trust what management says (Cohen, 1977; Kumar \& Ghadially, 1989).

\section{Fairness}

Fairness, like politics, is a multidimensional concept. In the present case, we examined what Greenberg (1993) calls "interactional justice." Interactional justice occurs when employees believe that concerns they elevate to their supervisor will be given a fair hearing by management. Reports by Bies and Moag (1986), Bies and Shapiro (1987), Shapiro (1993), and Shapiro and Brett (1991) have each demonstrated a relationship between perceived interactional fairness and levels of compliance with organizational procedures and rules. It follows that compliance with safety procedures and rules would be affected by perceived fairness in the workplace.

\section{Management Support for Safety}

While a number of dimensions have been found to be related to safety climate, management support for safety stands out as a common factor (Brown \& Holmes, 1986; Coyle, Sleeman, \& Adams, 1995; Dedobbeleer \& Beland, 1991; Zohar, 1980). Management support for safety can take two forms because both managers and supervisors comprise management. Managers generally indicate their safety supportindirectly. They establish priorities (i.e., policies, procedures, and goals), set production schedules that may accommodate to safe operations, and they control the incentives for complying with those priorities (e.g., compensation, awards, discipline). Supervisors, on the other hand, are the conduit linking management safety concerns to the shop floor. Therefore, they indicate management support for safety relatively more directly than do mangers (Kozlowski \& Doherty, 1989). Supervisors monitor compliance with management's direction, and they provide feedback to employees regarding the appropriateness of their behaviors. Supervisors also provide input to management regarding employee compliance or negligence (Niskanen, 1994). Such visible actions on the part of supervisors more directly communicate management support for safety than many actions taken by managers.

\section{Safety Outcomes}

Another important issue relates to identifying measures that are indicative of workplace safety. Vojrecky and Schmitz (1986) reported results from a survey of 124 occupational health practitioners, indicating that the assessment of safety criteria presented a barrier in determining the effectiveness of most safety programs. Common sense would dictate that observed accident rates present an indisputable direct outcome measure for safety interventions. However, such measures are often problematic. There are four factors that can affect reliability: restriction of variance, random influences, inaccurate reporting, and variability in accident severity. First, because accidents are normally rare events, accident rate data can be statistically unreliable due to restriction of variance (e.g. . Menckel \& Carter, 1985; Zohar, 1980). Second, accidents are not always under the control of job incumbents. No matter how compliant employees may be with safety procedures, extrancous random influences can cause or contribute to accidents. Therefore, uncontrollable events can also produce unreliability, especially if restriction of variance is a problem. Third, accidents are not always consistently recorded. There can be incentives for both the over reporting and under reporting of accidents. Either under reporting, over 
reporting, or both can lead to unreliable measures. Fourth, the level of accident severity can affect reliability. Washing out sawdust from an employee's eye might go unrecorded, whereas surgical removal of a sliver from an employee's eye is more likely to become a matter of record. One observable alternative to accident rates is the cost of an accident, but cost data can be more unseliable than rates. An accident must be recorded before a cost can be estimated, and estimates themselves involve judgment (c.g., does one include insurance, lost time from work, interrupted productivity?). A second alternative is a safety audit, however, audits are costly to conduct and rest upon observable conditions. A frequent weakness of audits is a lack of connection to behaviors. Moreover, audit data are often subject to unreliability caused by the four factors mentioned above.

Self reports of safety behaviors and perceptions offer an alternative criterion measure for determining workplace safety (e.g., Dejoy, 1994; Hofmann, Jacobs \& Landy, 1995; Janssens, Brett \& Smith, 1995). Although common method variance can inflate validities, it is possible to estimate their reliability (Cronbach, 1951). Safety perceptions are more likely to be valid in the one-tailed sense. When accident rates are very rare, respondents might over estimate their safety out of complacency. However, it is hard to believe that anonymous respondents would underestimate their level of safety if people around them were being injured on a regular basis.

\section{HYPOTHESES}

Witt, Helman, and Hilton (1994) established that management support for safety can mediate the relationship between climate and safety outcomes. Figure 1 presents the results of their path analysis. Although Figure 1 establishes a relationship between climate, management support, and safety, it provides limited insight into the dynamics of management's role in influencing safety. In this study, we therefore pursued several additional hypotheses that followed from Witt, Helman, and Hilton.

Following the literature reviewed above, we first hypothesized that the politics-safety relationship would be mediated by manager support for safety, whereas the fairness-safety relationship would be mediated by supervisor support for safery. Second we hypothesized that the managerial support mediation effect would be more pronounced in relationship to perceived

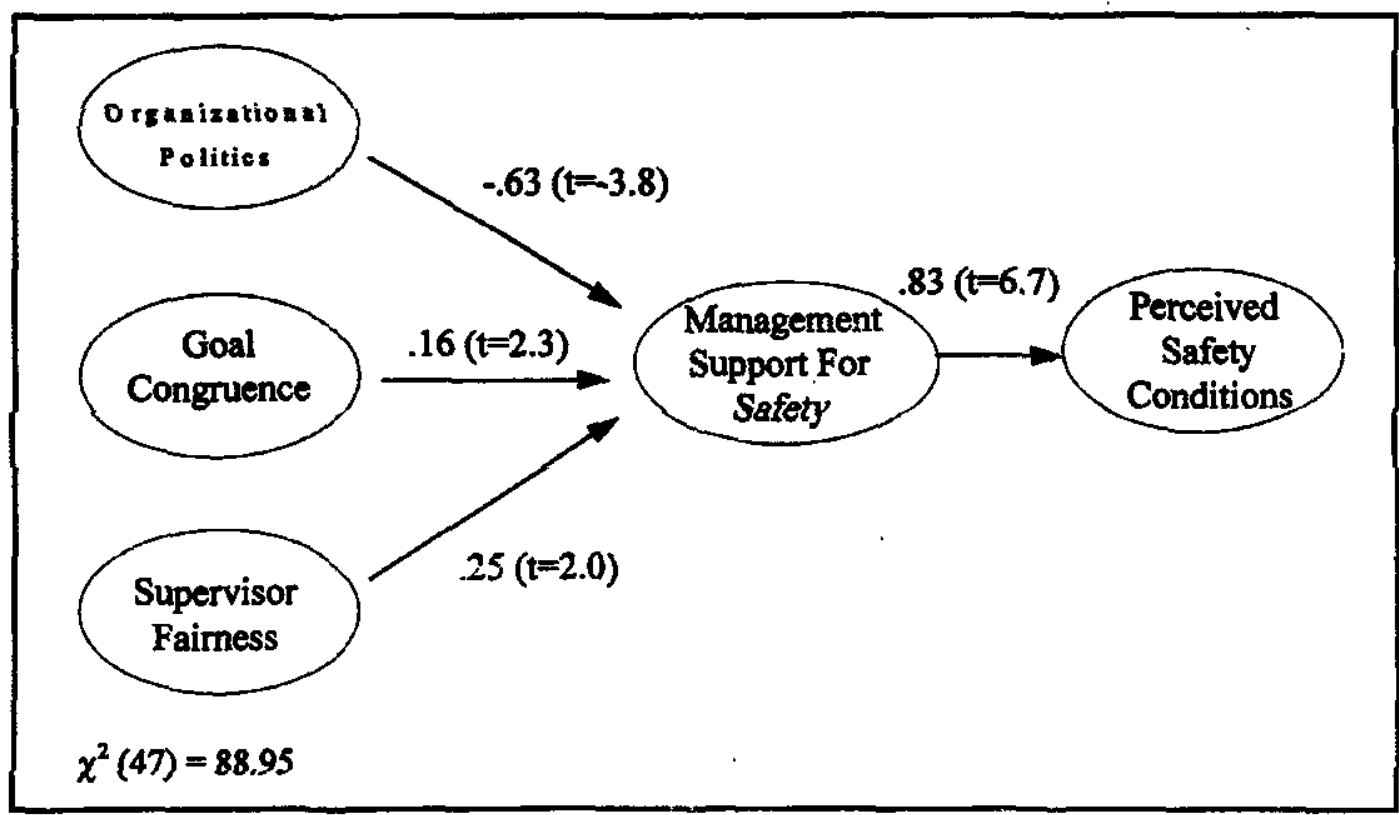

Figure 1. Results of Path Analysis 
safety conditions, whereas the mediator effect of supervisor support would be most pronounced in relationship to perceived safety compliance. Third, we hypothesized that this expanded model would successfully replicate on a second data set.

\section{METHOD}

A safety climate survey was administered at the Federal Aviation Administration's (FAA) Logistics Center in 1992 and 1995. The Logistics Center provides spare parts for all $\mathrm{FAA}$ air navigation aids, air traffic control equipment, and FAA facility physical plant materials (e.g., air conditioner parts, back-up generator parts). In addition to its warehousing mission, the Center includes a large fabrication shop for altering or manufacturing unique replacements, as well as a large administrative office to coordinate requests for parts and equipment, to purchase equipment and raw materials, as well as to ship new, fabricated, or repaired materials.

The 1995 survey was a shoreer version of the 1992 survey. The 1992 sample consisted of 350 of the 507 (69\%) employees who volunteered to complete the survey. The 1995 sample consisted of 329 of the 662 (50\%) employees who volunteered to complete the survey during a mandatory monthly safety meeting. The dimensions of interest on both surveys consisted of perceptions of organizational politics, interactional fairness, manager and supervisor support for safery, and perceptions of safety conditions and workforce compliance with safety. The irems common to both surveys were nearly identical. However, the 1992 measures of safety perceptions and management support for safety (see Figure 1) were rescored in 1995 to create separate measures of safety conditions and safety compliance, and manager and supervisor support for safety, respectively. Finally, goal congruence, which was assessed in the 1992 survey, was dropped in 1995 (to reduce the time and administrative complexity of the survey, at management's request). Assessment of congruence required using four separate questionnaires. Based upon the small contribution of congruence presented in Figure 1, we agreed not to assess congruence in 1995.

\section{Measures}

Politics was measured using a four-item scale based upon the Kacmar and Ferris (1991). "go along to get along" construct (e.g., "Some employees may hesitate to speak up for fear of retaliation."). Fairness was measured using a four-item scale based upon Shapiro's (1993) notion of interactional fairness (e.g., "My supervisor considers my viewpoint when making decisions that affect me."). Manager support for safety was measured using a four-item scale following Dedobbeleer and Béland (1991; e.g., "Management places worker safery as a top priority."). Supervisor support for safety used a four-item scale, also after Dedobbeleer and Beland (e.g., "My supervisor tells management about unsafe situations."). Safety outcomes included a four-item scale that as red about safery conditions (e.g., "Aisles/passageways and working areas are free of tripping hazards. Compliance with safety rules (e.g., "To what extent do most people in your section use equipment designed to protect thernselves."). All items were measured on five-point (strongly disagree to strongly agree) Likert-type scales. Accident rate data were also obtained from organization records.

\section{RESULTS}

Table 1 presents the means for the revised 1992 and 1995 scores, their standard deviations, and coefficient alpha reliability estimates. As can be seen, the rescoring of management support and perceived safery did nor adversely affect score reliabilities for either the 1992 or 1995 samples. As in the Witt, Helman, and Hilton (1994) study, accident rate data were once again found to be too unreliable to include in the analysis.

\section{Measurement Models}

Prior to examining relationships among the measured dimensions, the models for each construct were established using the 1992 data. First, the constructs were assessed individually. Model fit was examined, and adjustments were macie in an exploratory fashion. Next, constructs were examined in pairs. Perceptions of organizational politics and fairness were combined first, followed by management and supervisor support for safety, followed by safety conditions and safery 
TABLE 1.

Measurement scales used in the 1992 Safety Climate Questionnaire

\begin{tabular}{|c|c|c|c|c|c|c|c|}
\hline Scale Dimension & $\begin{array}{l}\begin{array}{l}\text { NR. } \\
\text { ltems }\end{array} \\
\end{array}$ & $\begin{array}{l}\text { '92 } \\
\text { Mean }\end{array}$ & $\begin{array}{l}\text { '92 } \\
\text { Std. } \\
\text { Dev. }\end{array}$ & $\begin{array}{l}92 \\
\text { Alpha }\end{array}$ & $\begin{array}{l}95 \\
\text { Mean }\end{array}$ & $\begin{array}{l}' 95 \\
\text { Std. } \\
\text { Dev. }\end{array}$ & $\begin{array}{l}95 \\
\text { Alpha }\end{array}$ \\
\hline $\begin{array}{l}\text { Organizational Politics } \\
\text { Fairness } \\
\text { Management Support for Safety }\end{array}$ & $\begin{array}{l}4 \\
4\end{array}$ & $\begin{array}{l}3.13 \\
3.58\end{array}$ & $\begin{array}{l}.97 \\
1.07\end{array}$ & $\begin{array}{l}.72 \\
.87\end{array}$ & $\begin{array}{l}3.04 \\
3.71\end{array}$ & $\begin{array}{l}.94 \\
.96\end{array}$ & $\begin{array}{l}.83 \\
.90\end{array}$ \\
\hline $\begin{array}{l}\text { Manager Support } \\
\text { Supervisor Support } \\
\text { Perceived Safety }\end{array}$ & $\begin{array}{l}4 \\
4\end{array}$ & $\begin{array}{l}3.18 \\
3.62\end{array}$ & $\begin{array}{l}.75 \\
.82\end{array}$ & $\begin{array}{l}.80 \\
.79\end{array}$ & $\begin{array}{l}3.67 \\
3.81\end{array}$ & $\begin{array}{l}.66 \\
.70\end{array}$ & $\begin{array}{l}.74 \\
.85\end{array}$ \\
\hline $\begin{array}{l}\text { Safety Conditions } \\
\text { Safety Compliance }\end{array}$ & $\begin{array}{l}4 \\
5\end{array}$ & $\begin{array}{l}3.29 \\
3.25\end{array}$ & $\begin{array}{l}.85 \\
.78\end{array}$ & $\begin{array}{l}.62 \\
.74\end{array}$ & $\begin{array}{l}3.27 \\
3.58\end{array}$ & $\begin{array}{l}.64 \\
.57\end{array}$ & $\begin{array}{l}.60 \\
.75\end{array}$ \\
\hline
\end{tabular}

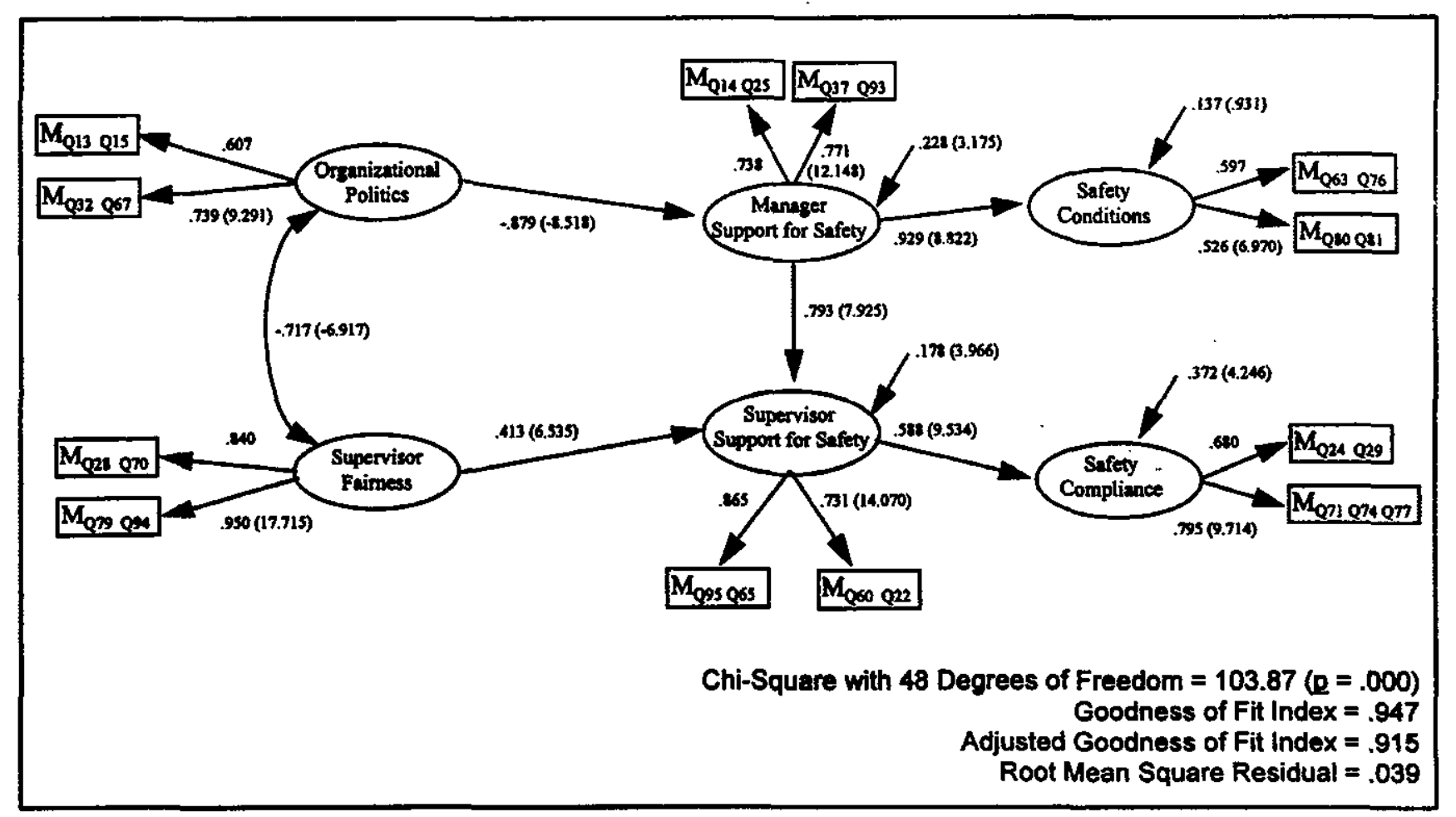

Figure 2. Model of Organization Climate, Safety Climate and Safety Perceptions for 1992 Data (structural estimates are standardized coefficients, and t-values are in parentheses). 
compliance. Finally, these scores were assessed in combination. All constructs were found to have good fit with no significant crossloadings. These analyses identified correlations among the error terms of some items. Correlations were eliminated by forming pairs of items averaged together to form "mini-means" following Berstein and Teng (1989).

\section{Structural Relationships}

After the new measurement model for the constructs was fully developed, the hypothesized structural relationships were tested. The expanded and revised basic model (Figure 2) was first tested. Figure 2 also presents the results of the structural assessment of the 1992 data. Consistent with our first hypothesis, the general mediator role of management support for safety was significant, even though manager and supervisor support factors were treated as distinct constructs. That is, there was a direct effect between each climate measure specified as affecting each specified management support for safety measure. There was also a direct effect between each management support measure and each specified safety outcome. There were no significant paths between any climate and safety outcomes measure.

Consistent with our second hypothesis, Figure 2 shows that organizational politics was related to perceptions of management support, which in turn influenced perceptions of general safety conditions. Supervisor fairness influenced perceived supervisor support for safety, which in turn, influenced perceptions of safety compliance. Finally, manager support for safety was also found to influence perceptions of supervisor support. This latter result was not predicted, but is consistent with the general leadership research literature (see, for example, the lengthy review in Conger, 1989).

The revised 1992 model established by Witt, Helman, and Hilton (1994) suppores the idea that an organization's general climate affects safety through management actions. Specifically, it shows that management influence is pervasive, not only influencing climate and safety but also affecting the influence of supervisors on safery perceptions. However, because of the exploratory development of both the measurement and structural models, it is possible that the model that emerged did so because of capitalization on chance variations in the 1992 data. Therefore, the model was reassessed on the 1995 sample. The 1992 model was applied directly to the 1995 data using the same items, and free and fixed parameters from the previous model without prior assessment of indicator measures or structure. The results of this analysis are summarized in Figure 3. Consistent with our third hypothesis, the expanded model fit both the 1992 and 1995 data sets. The fit statistics for the models indicate the 1992 data provided a somewhat better fit than the 1995 data.

\section{DISCUSSION}

The present study extended earlier work demonstrating the important role managers play in establishing an organizational climate that affects workplace safety. The expanded model presented here clarifies that managers play 2 role in promoting safety by affecting the degree of politics in their organization's climate, which in turn, impacts perceived safety conditions. The expanded model also clarifies that supervisors play a role in promoting safety by affecting the level of fairness in their organization's climate, which in turn, impacts perceived compliance with safety rules. It would have been an added bonus if we could have tested these models using accident rate data, however, this was not possible. Previous literature suggests that accident rate data are not reliable in a great many organizations. As we noted in the introduction, unreliability may not be due to lax book keeping but partly due to the rarity of accident events in many organizations.

We would argue that perceptual data, i.e., self reports, might be the preferred criteria for safety research. Minor accidents often go unreported, yet those unreported events may be the best indicator of improving or worsening safety conditions that might eventually lead to serious injury. Members of the workforce out on the shop floor are likely to be sensitive to the type and frequency of accidents that go underreported. Their perceived sense of workplace safety conditions might, therefore, be a better indicator of safety risk than the routine reports and other information available to management. 


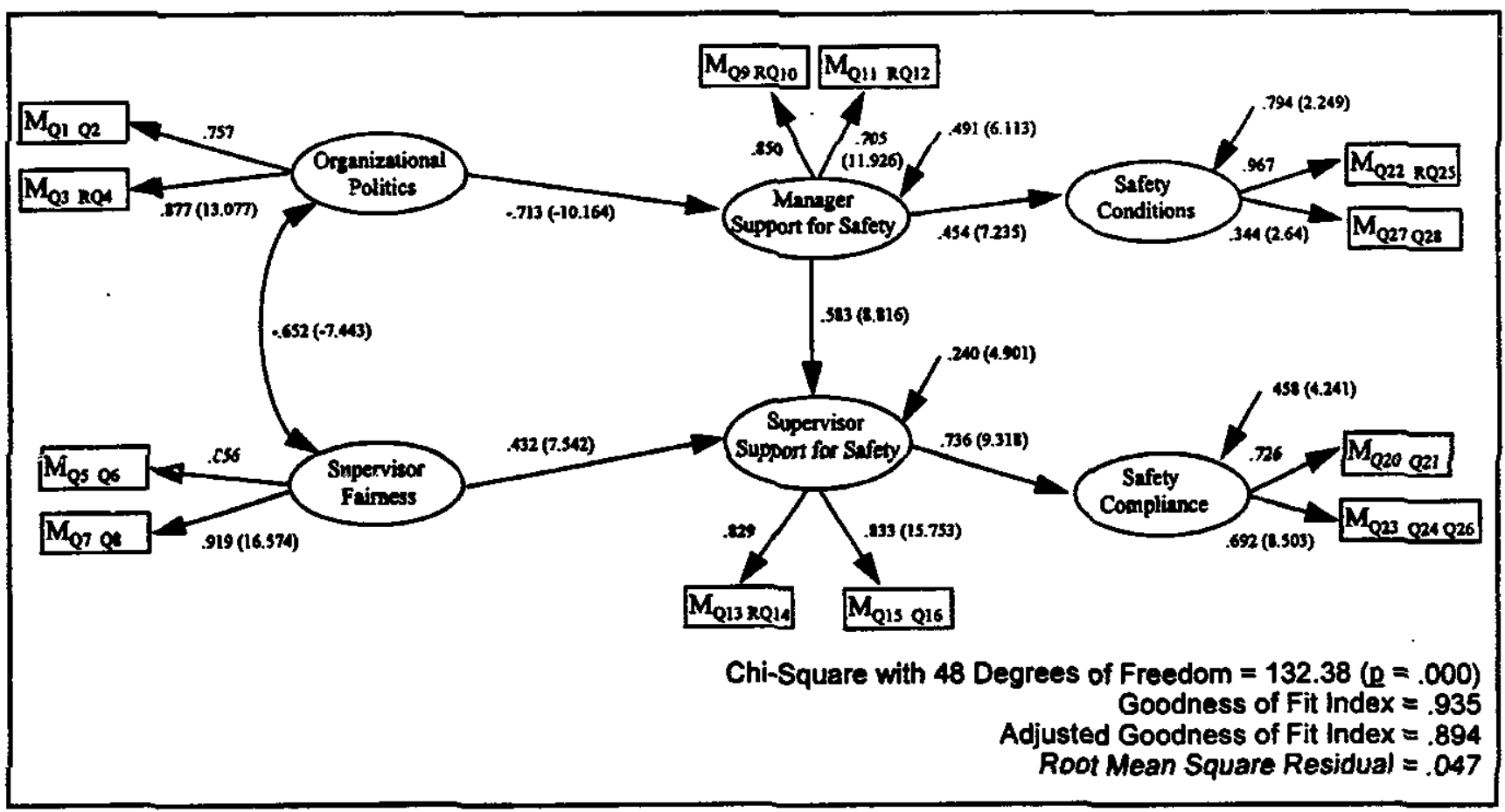

Figure 3. Model of Organization Climate, Safety Climate and Safety Perceptions for 1995 Data (structural estimates are standardized coefficients, and $t$-values are in parentheses).

There are some noticeable shortcomings in the new model presented here. One might expect a relationship between safety compliance and general safety conditions. A significant relationship did not emerge during the exploratory structural analysis. However, when the model was confirmed in 1995, the analyses produced a large modification index, suggesting the model would benefit from freeing this path. However, because hypotheses being tested were aimed at confirming the structure of the model for the 1992 sample with the 1995 sample, additional struciure changes were not assessed.

One can debate endlessly the nuances of any structural model. The best utility of confirmatory analyses is to add confidence to hypothesized relationships by examining them over time and in varying venues. This test used a very brief set of items at two points in time. We confirmed the relationships that we expected to find, based upon prior research and theory. Our results not only demonstrated that management plays an important role in maintaining a safe workplace, which should be obvious, but that managers and supervisors do so in differing w2ys. Managers appear to influence safery by influencing the politics of communication (what is elevated to their attention), whereas supervisors do so by influencing the fairness by which they interact with employees perhaps leading to employee impressions of whether supervisors will elevate concerns to management. 


\section{REFERENCES}

Berstein, I.H. \& Teng, G. (1989). Factoring items and factoring scales are different: Spurious evidence for multidimensionality due to item categorization. Psychological Bulletin, 105, 467-77.

Bies, R.J. \& Moag, J.S. (1986). Interactional justice: Communication criterin of fairness. In R.J. Lewicki, B.H. Sheppard and M.H. Bazerman (Eds). Research on negotiation in organizations, (Vol 1., p. 43-55). Greenwich, CT: JAI Press.

Bies, R.J. \& Shapiro, D.L. (1987). Interactional fairness judgment: The influence of causal accounts. Social Justice Research, 1, 199-218.

Brown, R.L. \& Holmes, H. (1986). The use of a factoranalytic procedure for assessing the validity of an employee safety climate model. Accident Prevention and Anabysis, 18, 455-70.

Cleveland, R.J., Cohen, H.H., Smith, M.J., and Cohen, A. (1978). Safety program Safety program practices in recordholding plants. Cincinnati, $\mathrm{OH}$ : National Institute for Occupational Safety and Health.

Cohen, A. (1977). Factors in successful occupational safety programs. Joumal of Safety Research, 2, 16878.

Cohen, A. Smith, M, \& Cohen, H.H. (1975). Safety program practices in high vs. low accident rate companies - An interim report. US Department of Health, Education, and Welfare Publication \# 75-185. Cincinnati, OH: National Institute for Occupational Safety and Health.

Conger, J.A. (1989). The charismatic leader. San Francisco, CA: Jossey-Bass.

Coyle, I.R., Sleeman, S.D. \& Adams, N. (1995). Safety climate. Journal of Safety Research, 26, 247-54.

Cronbach, L.J. (1951). Coefficient alpha and the internal structure of tests. Psychometirica, 16, 297-334.

Dedobbeleer, N., \& Beland, F. (1991). A safety climate measure for construction sites. Journal of Safety Research, 22, 97-103.

Dejoy, D. (1985). Atrributional processes and hazard control management in industry. Journal of Safety Research, 16, 61-71.

Dejoy, D. (1994). Managing safety in the workplace: An attribution theory analysis and model. Journal of Safety Research, 25, 3-17.
Drory, A. \& Romm, T. (1990). The definition of organizational politics: A review. Human Relations, 43, 1133-1154.

Gandz, J. \& Murray, V. V. (1980). The experience of workplace politics. Academy of Management Review, 23, 237-51.

Greenberg, J. (1993). The social side of fairness: Interpersonal and information classes of organizarional justice. In R. Cropanzano (Ed.) Justice in the workplace: Approaching fairness in buman resource management (pp. 79-103). Hillsdale, NJ: Lawrence Earlbaum Assoc.

Hofmann, D.A., Jacobs, R. \& Landy, F. (1995). High relizbility process industries: Individual, micro, and macro organizational influences on safety performance. Journal of Safety Research, 26, 131-49.

Janssens, M., Brett, J.M., and Smith, F. (1995). Confirmatory cross-cultural research: Testing the viability of a corporation-wide safety policy. Academy of Management Journal, 38, 364-82.

Kacmar, K.M. \& Ferris, G.R. (1991). Perceptions of organizational politics scale (POPS): Development and construct validation. Educational and Pyychological Measurement, 51, 193-205.

Kozlowski, S.W.J. \& Doherty, M.L. (1989). Integration of climate and leadership: Examination of a neglected issue. Journal of Applied Psychology, 74, 546-53.

Kumar, P. \& Ghadially, R. (1989). Organizational politics and its effects on members in organizations. Human Relations, 2ㅡ, 305-14.

Madison, D.L., Allen, R.W., Porter, L.W., Renwick, P.A., \& Mayes, B.T. (1980). Organizational politics: An exploration of managers' perceptions. Human Relations, 33, 79-100.

Menckel, E. \& Carter, N. (1985). The development and evaluation of accident prevention routines: A case study. Journal of Safety Research, 16, 73-82.

Myers, S.D., \& Facteau, J.D. 1992, August. Understanding compliance behavior in occupational settings: Implications for proactive management strategies. Paper presented at the meeting of the Academy of Management, Las Vegas, NV.

Niskanen, T. (1994). Assessing the safery environment in work organization of road maintenance jobs. Accident Analysis and Prevention, 26, 27-39. 
Schneider, B. (1987). The people make the place. Personnel Psychology, 느, 437-54.

Schneider, B. \& Rentsch, J. (1988). Managing climates and cultures: A futures perspective. In: J. Hage (Ed.). Futures of organizations: Innovating to adapt strategy and human resources to rapid technological change (pp. 181-200). Lexington, MA: Lexington Books.

Shapiro, D.L. (1993). Reconciling theoretical differences among procedural justice researchers by reevaluating what it means to have one's views "considered": Implications for third-party managers. In R. Cropanzano (Ed.) Justice in the workplace: Approaching faimess in buman resource management (pp. 51-78). Hillsdale, NJ: Lawrence Earlbaum Assoc.

Shapiro, D.I \& Brett, J.M. (1991). Comparing the instrumental and value-expressive models of procedural faimess under conditions of high and low decision control. Paper presented at the National Academy of Management Meeting, Miami, FL.
Tuttle, T.C., Dachler, H.P. \& Schneider, B. (1975). Organizational psychology. In: B.L. Margolis and W.H. Kroes (Eds.), The human side of accident prevention, (pp. 7-44). Springfield, $\mathrm{II}_{i}$ : Charles $\mathrm{C}$. Thomas.

Vancouver, J.B. \& Schmidt, N.W. (1991). An exploratory examination of person-organization fit: Organizational goal congruence. Personnel Psychology, 华, 333-52.

Vojrecky, M.A.\&Schmizz, M.F. (1986). Program evaluation and health and safety training. Journal of Safety Research, 17, 57-63.

Witt, L.A., Helman, C., \& Hilton, T.F., (1994). Management influences on perceived safety. Paper presented at the annual Meeting of the American Psychological Society, San Francisco, CA.

Zohar, D. (1980). Safety climate in industrial organizations: Theoretical and applied implications. Journal of Applied Psychology, 65, 96-102. 